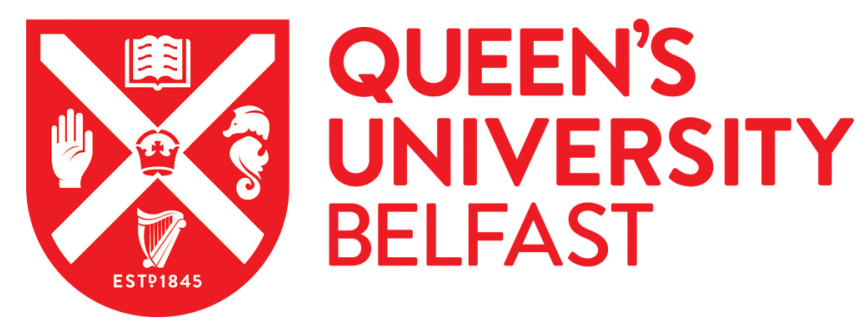

\title{
Total Synthesis of the Antitumor Macrolides, (+)-Brefeldin A and 4-Epi-Brefeldin A from D-Glucose: Use of the Padwa Anionic Allenylsulfone [3+2]-Cycloadditive Elimination To Construct Trans- Configured Chiral Cyclopentane Systems
}

Xiong, Z., \& Hale, K. J. (2016). Total Synthesis of the Antitumor Macrolides, (+)-Brefeldin A and 4-Epi-Brefeldin A from D-Glucose: Use of the Padwa Anionic Allenylsulfone [3+2]-Cycloadditive Elimination To Construct TransConfigured Chiral Cyclopentane Systems. Organic Letters, 18(17), 4254-4257.

https://doi.org/10.1021/acs.orglett.6b02002

Published in:

Organic Letters

Document Version:

Publisher's PDF, also known as Version of record

Queen's University Belfast - Research Portal:

Link to publication record in Queen's University Belfast Research Portal

\section{Publisher rights}

(C) 2016 American Chemical Society

This is an open access article published under an ACS AuthorChoice License, which permits copying and redistribution of the article or any adaptations for non-commercial purposes.

\section{General rights}

Copyright for the publications made accessible via the Queen's University Belfast Research Portal is retained by the author(s) and / or other copyright owners and it is a condition of accessing these publications that users recognise and abide by the legal requirements associated with these rights.

Take down policy

The Research Portal is Queen's institutional repository that provides access to Queen's research output. Every effort has been made to ensure that content in the Research Portal does not infringe any person's rights, or applicable UK laws. If you discover content in the Research Portal that you believe breaches copyright or violates any law, please contact openaccess@qub.ac.uk. 


\title{
Total Synthesis of the Antitumor Macrolides, (+)-Brefeldin A and 4-Epi-Brefeldin A from D-Glucose: Use of the Padwa Anionic Allenylsulfone [3 + 2]-Cycloadditive Elimination To Construct Trans- Configured Chiral Cyclopentane Systems
}

\author{
Ziyue Xiong and Karl J. Hale*
}

The School of Chemistry \& Chemical Engineering and the Centre for Cancer Research and Cell Biology (CCRCB), The Queen's University Belfast, Stranmillis Road, Belfast BT9 5AG, Northern Ireland, United Kingdom

\section{Supporting Information}

ABSTRACT: A new synthesis of (+)-brefeldin A is reported via Padwa allenylsulfone $[3+2]$-cycloadditive elimination. Cycloadduct 13 was initially elaborated into iodide 27 , which, following treatment with $\mathrm{Zn}$, gave aldehyde 28 whose $\mathrm{C}(9)$ stereocenter was epimerized. Further elaboration into enoate 38 and Julia-Kocienski olefination with 5 subsequently afforded 39, which was deprotected at $\mathrm{C}(1)$ and $\mathrm{O}(15)$. Yamaguchi macrolactonization of the seco-acid thereafter afforded a macrocycle that underwent O-desilylation and inversion at $\mathrm{C}(4)$ to give (+)-brefeldin $\mathrm{A}$ following deprotection.

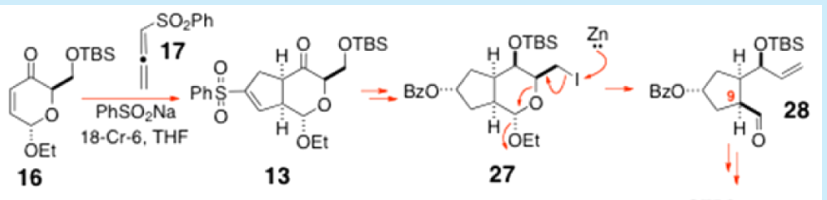

16

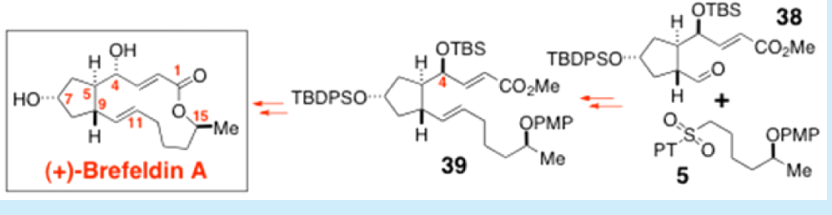

$\mathrm{T}^{\mathrm{h}}$ he structurally complex antitumor macrolide, $(+)$-brefeldin $A,{ }^{1}$ has occupied an almost iconic position within the field of stereocontrolled natural product total synthesis, ${ }^{2}$ due to the significant challenges it poses for complex chiral cyclopentane ring construction. In this connection, and following a recent successful deployment of the Padwa allenylsulfone anionic [3+ 2 ]-cycloadditive-elimination ${ }^{3}$ in the synthesis of (-)-echinosporin, ${ }^{4}$ we became interested in evaluating whether this novel cyclopentene ring-assembly method might prove useful for the stereoselective construction of chiral bicyclic cyclopentanoids with a trans-ring junction, and in this connection, (+)-brefeldin A immediately sprung to mind as a target.

(+)-Brefeldin A has elicited considerable medicinal interest over the years, ${ }^{5}$ due to the fact that its water-soluble $7-\mathrm{N}, \mathrm{N}$ dimethylglycinate pro-drug, breflate, was reported to be a powerful inhibitor of human melanoma xenograft growth in mice. ${ }^{6}$ Despite these early exciting findings, subsequent more detailed pharmacological evaluation of breflate and other brefeldin A pro-drugs at higher dosages $(20 \mathrm{mg} / \mathrm{kg}) \mathrm{did}$ eventually reveal that they could bring about seizures in mice and cause noticeable neurodegeneration. ${ }^{7}$ Ultimately, these observations led to molecules of the brefeldin class not proceeding into human clinical development. It is now believed that much of the toxicity of (+)-brefeldin A derives from its blockade of the interaction between the adenosine diphosphate ribosylation factor 1 (Arf1)-GDP (guanosine diphosphate) complex with the Sec7 domains of various Arf-GTPase exchange factors, which interferes with their normal functioning. ${ }^{7-9}$ Despite these problems, work has continued on the synthesis of new brefeldin A analogues, ${ }^{5}$ with many teams retaining the hope that they might identify a structurally modified congener that will have an improved activity/toxicity profile. It was with such thoughts in mind, that we too commenced synthetic efforts on (+)-brefeldin A, and herein, we now report a new, fully stereocontrolled, enantioselective synthesis.

In our original retrosynthetic plan for $(+)$-brefeldin A (1) (Scheme 1), we sought to access 1 from the seco-acid 2 by regioselective macrolactonization. Compound 2 would emerge from 3 by cleavage of all the protecting groups, while 3 would derive from 6 by the successful implementation of $E$-olefin crossmetathesis and Julia/Kocienski olefination ${ }^{10}$ tactics on $\mathbf{6}$ and 4, respectively. Aldehyde 6 would possibly emerge from 8 by pyrrolidine-induced epimerization, while 8 might be securable from the pyranoside 9 by Vasella reductive ring cleavage. ${ }^{11}$ Further retrosynthetic tracing of $\mathbf{9}$ to $\mathbf{1 2}$ suggested compounds 10 and 11 as intermediates, with 11 emerging from a sulfone carbanion oxidation on $\mathbf{1 2}$ and $\mathbf{1 0}$ from a ketone reduction. A double Mitsunobu inversion ${ }^{12}$ on $\mathbf{1 0}$ with benzoic acid and an $\mathrm{O}$ desilylation and iodination would thereafter complete the route to 9. The requisite Padwa anionic [3+2]-cycloadduct 13 had already been prepared from 16 and $\mathbf{1 7}$ during our development of a new pathway to (-)-echinosporin, ${ }^{4}$ and so now we envisioned converting 13 into 12 by a simple catalytic hydrogenation reaction.

With this summary of our strategy in mind, we repeated the work of Flasz and $\mathrm{Hale}^{4}$ to acquire cycloadduct 13 in the previously reported $56 \%$ yield (Scheme 2 ). The alkene in 13 was

Received: July 9, 2016

Published: August 19, 2016 
Scheme 1. Our Retrosynthetic Plan for (+)-Brefeldin A

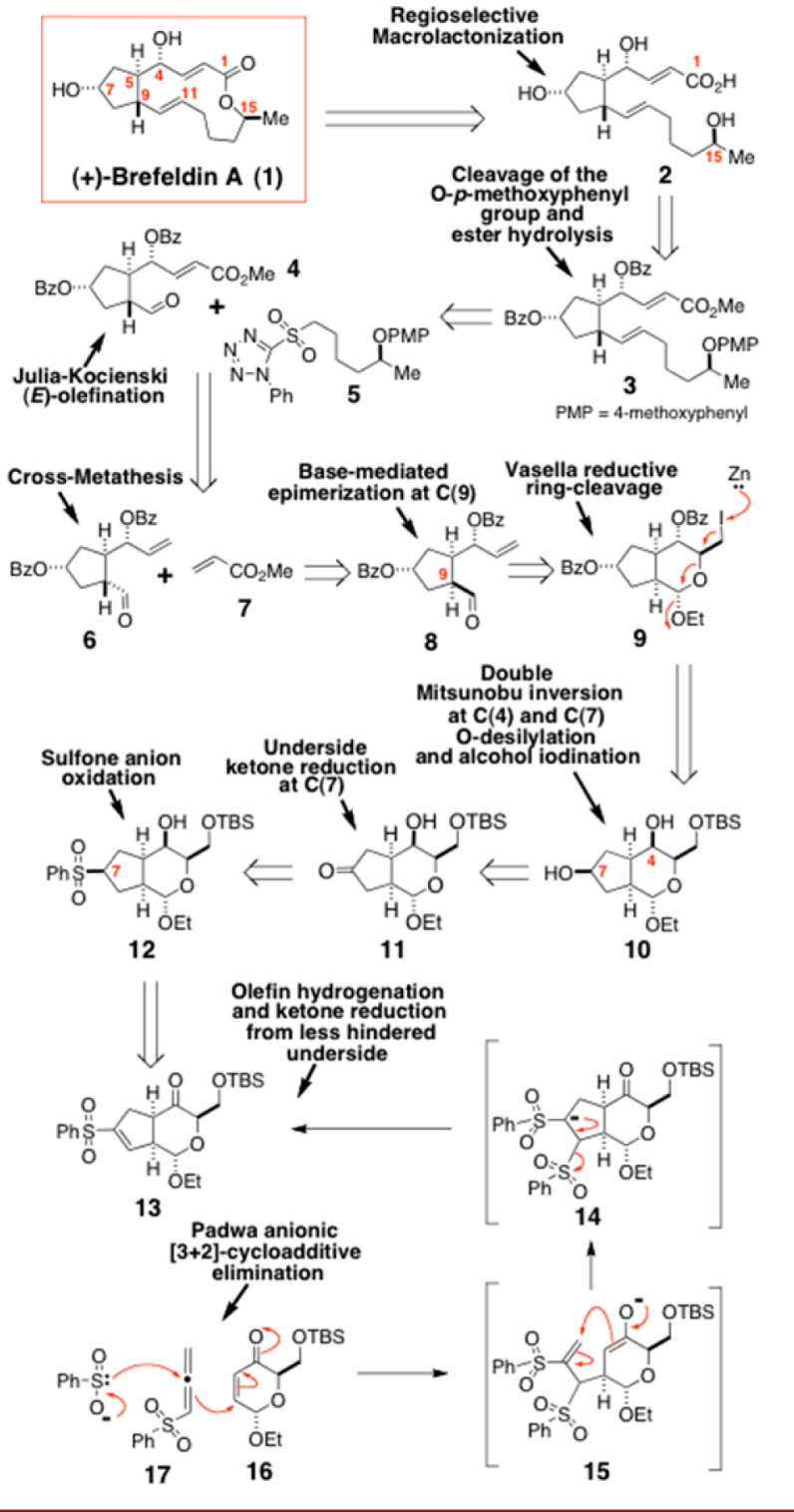

Scheme 2. Our Attempted Synthesis of Ketone 11

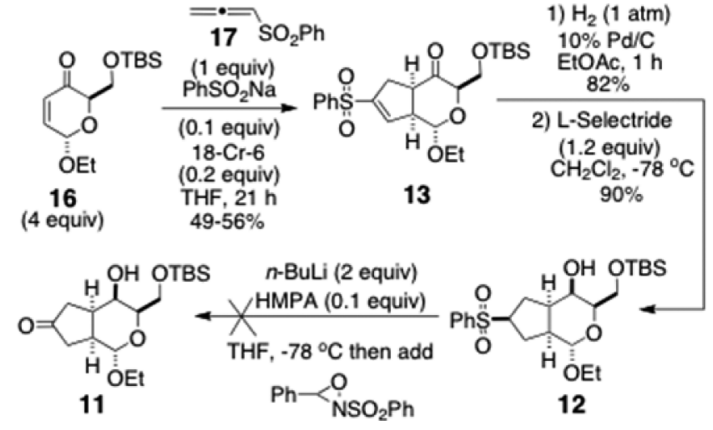

hydrogenated. The cyclopentylsulfone next had its ketone reduced from its less hindered underside with L-Selectride to provide alcohol 12 with total stereocontrol. Conversion of $\mathbf{1 2}$ into 11 was now attempted by forming the dianion of 12 with 2 equiv of $n$-BuLi in THF/HMPA at $-78{ }^{\circ} \mathrm{C}$ and oxidizing this with the Davis oxaziridine. ${ }^{13}$ Disappointingly, this reaction failed to give any of the desired ketone $\mathbf{1 1}$ even when attempted under a range of conditions.

We therefore sought to arrive at iodide 9 by a pathway (Scheme 3 ) that set off from the known (8S)- $\alpha$-hydroxy ketone

Scheme 3. Our Attempted Early Stage Double Mitsunobu Inversion of Triol 21 at $C(4)$ and $C(7)$

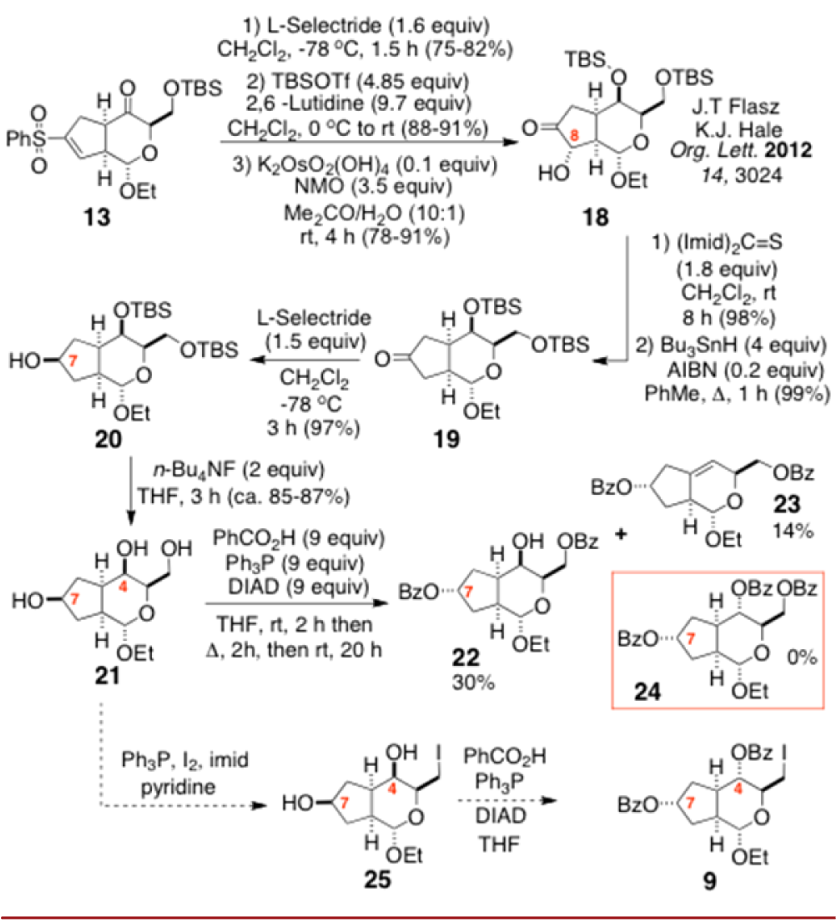

18, preparable from $13 .^{4}$ On this occasion, we hoped to access 9 from triol 21 by selective iodination and double invertive Mitsunobu displacement of 25 with $\mathrm{PhCO}_{2} \mathrm{H},{ }^{12}$ but first we established whether such a double inversion would indeed be feasible on 21 to obtain 24. Hydroxy ketone 18 was thus successfully converted into 19 by Barton deoxygenation ${ }^{14}$ of the (8S)-O-thiocarbonylimidazolide with $\mathrm{Bu}_{3} \mathrm{SnH} /$ cat. AIBN in $\mathrm{PhMe}$ at reflux for $1 \mathrm{~h}$. With regard to preparation of the $O$ thionocarbonylimidazolide, it proved essential not to add DMAP to the mix; otherwise, the epimeric $(8 R)-\mathrm{C}(8)-O$-thionocarbonylimidazolide would start to arise, and this would subsequently not undergo Barton deoxygenation with $\mathrm{Bu}_{3} \mathrm{SnH} / \mathrm{AIBN}$ ! With 19 in hand, L-Selectride reduction gave alcohol 20 as a single isomer, and O-desilylation led to 21 . Despite many attempts, we were unsuccessful in effecting the desired double Mitsunobu inversion on 21 to obtain 24 .

Instead, only the di-O-benzoate $\mathbf{2 2}$ and elimination product $\mathbf{2 3}$ were formed in 30 and $14 \%$ yield, respectively. This result and those of other $\mathrm{C}(4)$ inversion studies that we performed on related substrates all confirmed that $\mathrm{C}(4)$ inversion would have to be delayed until the very final stages of the synthesis when the pyranoid ring had been fully dismantled.

Given this setback, we elected to make aldehyde $\mathbf{3 0}$ our new synthetic objective (Scheme 4). Alcohol 20 was thus subjected to Mitsunobu displacement ${ }^{12}$ to obtain 26; this reaction proceeded in high yield $(81 \%)$ and gave a single product. Selective cleavage of the C(2)-OTBS group from $\mathbf{2 6}$ and iodination thereafter proceeded satisfactorily to deliver iodide 27 in $84 \%$ overall yield. Vasella reductive cleavage ${ }^{11}$ was next attempted with zinc dust in aqueous $i$-PrOH at reflux. It proved necessary to follow this reaction by TLC throughout to ensure that reduction of the 
Scheme 4. Our Synthesis of the New Alkenyl Aldehyde 29<smiles>[B-]OC1C(COCC)OC([SeH])C2CC(O)CC21</smiles>

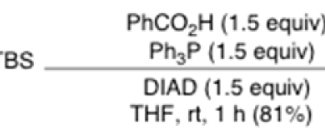

20

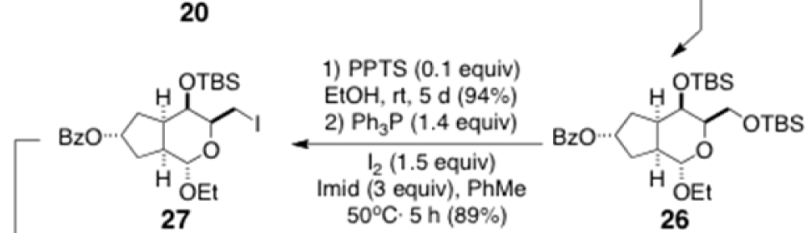

Zn dust

i- $\mathrm{PrOH} / \mathrm{H}_{2} \mathrm{O}$

$(5: 1)$
$\Delta, 3 \mathrm{~h}$

$95 \%$

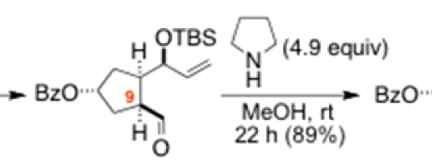

28
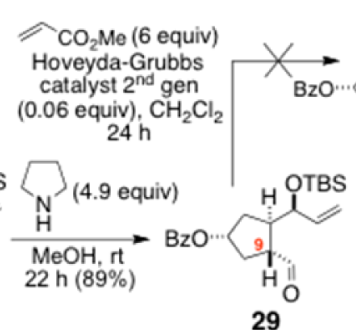

29

aldehyde also did not occur; a $3 \mathrm{~h}$ reaction time typically minimized this event and gave $\mathbf{2 8}$ in $95 \%$ yield. A variety of bases were then investigated to perform the desired epimerization of 28 into 29, but pyrrolidine soon emerged as the reagent of choice, giving a high yield of product with high stereoselectivity.

A fresh disappointment beset us when we discovered that the alkene in $\mathbf{2 9}$ was not a productive partner in olefin crossmetathesis with excess methyl acrylate to obtain $\mathbf{3 0}$ (Scheme 4). Given this undesired outcome, we decided to investigate whether a Wittig reaction might prove useful for enoate elaboration, but clearly, the adoption of this tactic would require reduction of the $\mathrm{C}(9)$-aldehyde and protection of the resulting alcohol to enable the $\mathrm{C}(3)$-aldehyde to be oxidatively unveiled. There was also the issue of $\mathrm{C}(4)$ inversion and macrolactonization to contend with much later in the synthesis. After due consideration, an orthogonal silyl ether protecting group strategy was eventually adopted, with aldehyde 29 being converted into differentially protected tri-O-silyl ether 33 (Scheme 5).

A four-step protocol accomplished this task (Scheme 5). In this, $\mathrm{NaBH}_{4}$ reduction of $\mathbf{2 9}$ delivered a primary alcohol that underwent $\mathrm{O}$-silylation with $\mathrm{TBSCl}$ and imidazole. Alkene 31 then had its $O$-benzoate reductively removed with $i-\mathrm{Bu}_{2} \mathrm{AlH}$ at low temperature. The resulting alcohol 32 was then $\mathrm{O}$-silylated with TBDPSCl and imidazole in $\mathrm{CH}_{2} \mathrm{Cl}_{2}$ at $\mathrm{rt}$. Initially, the use of cat. $\mathrm{OsO}_{4}$ and $\mathrm{NaIO}_{4}$ was pursued for the oxidative cleavage of alkene 33 , to obtain 35 , but this gave rise to a complex reaction mixture. In the end, the alkene of $\mathbf{3 3}$ was best dihydroxylated under standard Upjohn conditions with cat. $\mathrm{OsO}_{4}$ and excess $\mathrm{N}$ methylmorpholine $\mathrm{N}$-oxide. ${ }^{15}$ This afforded a single diol 34, whose stereochemistry was tentatively assigned as anti, using Kishi's empirical rule. ${ }^{16}$ This diol was then oxidatively cleaved with $\mathrm{Pb}(\mathrm{OAc})_{4}$, and the resulting aldehyde 35 Wittig olefinated to obtain enoate 36 as a single geometric isomer. Selective Odesilylation of 36 with cat. PPTS/EtOH at rt over 60 h cleanly gave alcohol 37 , which was converted into the aldehyde 38 by TEMPO/PhI $(\mathrm{OAc})_{2}$ oxidation. Julia/Kocienski olefination ${ }^{10}$ of 38 with the $N$-phenyltetrazolylsulfone $\mathbf{5}$ furnished the all $(E)$ alkene 39 as a single stereoisomer in $68 \%$ yield. Our new abridged synthesis of $5^{2 \mathrm{e}}$ from $45^{17}$ is presented in Scheme 6.

Ceric ammonium nitrate cleavage of the PMP group ${ }^{18}$ from 39 then ensued; the methyl ester was likewise cleaved with aq $\mathrm{LiOH}$.
Scheme 5. Completion of Our Syntheses of (+)-Brefeldin A (1) and 4-Epi-Brefeldin A (44) from Alkenyl Aldehyde 29
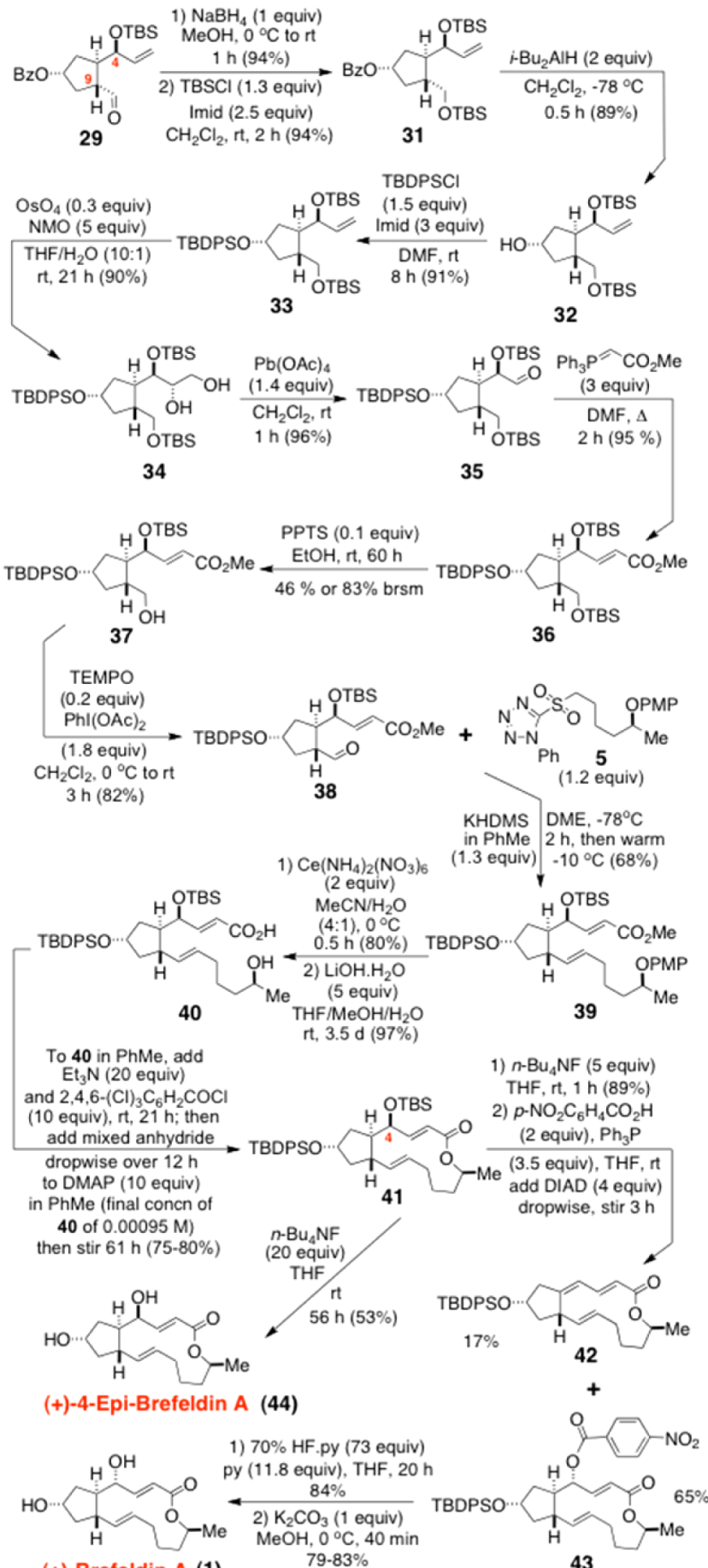

(+)-Brefeldin A (1) $79-83 \%$

43

A Yamaguchi macrolactonization ${ }^{19}$ of the seco-acid 40 was now accomplished at high dilution, as described in Scheme 5. Macrolactone 41 was formed in excellent yield, in what was a very clean reaction. Selective C(4) O-desilylation of 41 could subsequently be accomplished cleanly and rapidly with 5 equiv of $n-\mathrm{Bu}_{4} \mathrm{NF}$ in THF over $1 \mathrm{~h}$. The resulting alcohol was then subjected to Mitsunobu inversion with $\mathrm{Ph}_{3} \mathrm{P} / \mathrm{DIAD}$ and $p$ nitrobenzoic acid. ${ }^{12 c}$ The desired product 43 was isolated pure in $65 \%$ yield; elimination product $\mathbf{4 2}$ was also isolated in $17 \%$ yield by $\mathrm{SiO}_{2}$ flash chromatography. With pure 43 in hand, (+)-brefeldin A was readily accessed after HF-pyridine-induced 
Scheme 6. Synthesis of the $N$-Phenyltetrazolylsulfone 5

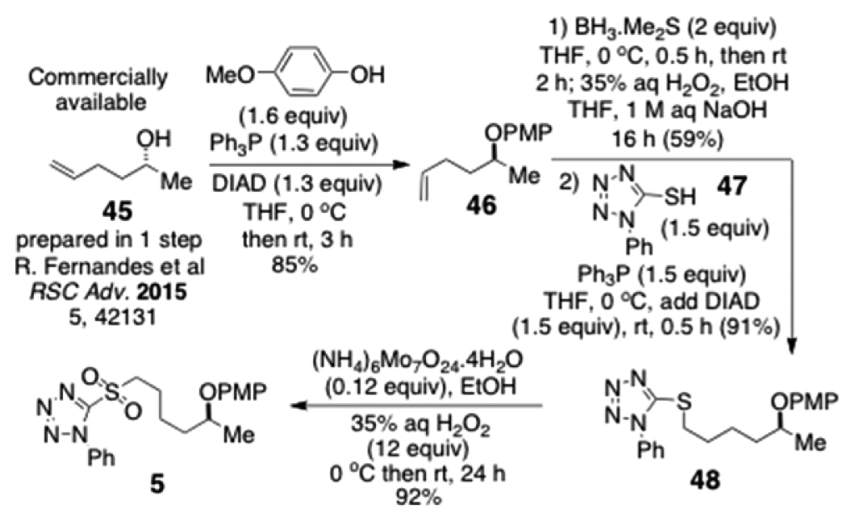

O-desilylation and brief treatment $(0.5 \mathrm{~h})$ with $\mathrm{K}_{2} \mathrm{CO}_{3}$ (1 equiv) in $\mathrm{MeOH}$ at $0{ }^{\circ} \mathrm{C}$. Following final purification by $\mathrm{SiO}_{2}$ flash chromatography, the natural product was obtained in $70 \%$ yield for the two steps and was spectroscopically identical with the spectra reported for (+)-brefeldin $\mathrm{A}$ in the literature in $\mathrm{CD}_{3} \mathrm{OD}^{2 \mathrm{f}}$ and $\mathrm{CDCl}_{3} \cdot{ }^{20} \mathrm{Cleavage}$ of the $\mathrm{O}$-silyl protecting groups from 41 with $n-\mathrm{Bu}_{4} \mathrm{NF}$ in THF afforded 4-epi-brefeldin $\mathrm{A},{ }^{2 \mathrm{~h}}$ as well.

In summary, a new total synthesis of (+)-brefeldin $\mathrm{A}$ was achieved from the Padwa $[3+2]$-cycloadduct 13. The utility of the latter cycloaddition was demonstrated for the preparation of trans-configured chiral cyclopentanes. New types of brefeldin analogues should now prove accessible.

\section{ASSOCIATED CONTENT}

Supporting Information

The Supporting Information is available free of charge on the ACS Publications website at DOI: 10.1021/acs.orglett.6b02002.

Full experimental procedures for all steps, as well as copies of the IR, HMRS, and ${ }^{1} \mathrm{H} /{ }^{13} \mathrm{C}$ NMR spectra of every intermediate $(\mathrm{PDF})$

\section{AUTHOR INFORMATION}

\section{Corresponding Author}

*E-mail: k.j.hale@qub.ac.uk.

Notes

The authors declare no competing financial interest.

\section{ACKNOWLEDGMENTS}

We thank QUB for a studentship and for funding this work.

\section{REFERENCES}

(1) (a) Singleton, V. L.; Bohonos, N.; Ullstrup, A. J. Nature 1958, 181, 1072. (b) Weber, H. P.; Hauser, D.; Sigg, H. P. Helv. Chim. Acta 1971, 54, 2763.

(2) For previous (+)-brefeldin A total syntheses in reverse chronological order, see: (a) Fuchs, M.; Furstner, A. Angew. Chem., Int. Ed. 2015, 54, 3978. (b) Wu, Y.; Gao, J. Org. Lett. 2008, 10, 1533. (c) Seo, S.-Y.; Jung, J.-K.; Paek, S.-M.; Lee, Y.-S.; Kim, S.-H.; Suh, Y.-G. Tetrahedron Lett. 2006, 47, 6527. (d) Wu, Y.; Shen, X.; Yang, Y.-Q.; Hu, Q.; Huang, J.-H. Tetrahedron Lett. 2004, 45, 199. (e) Trost, B. M.; Crawley, M. L. J. Am. Chem. Soc. 2002, 124, 9328. (f) Kim, D.; Lee, J.; Shim, P. J.; Lim, J. I.; Jo, H.; Kim. J. Org. Chem. 2002, 67, 764. (g) Suh, Y.G.; Jung, J.-K.; Seo, S.-Y.; Min, K.-H.; Shin, D.-Y.; Lee, Y.-S.; Kim, S.-H.; Park, H.-J. J. Org. Chem. 2002, 67, 4127. (h) Wang, Y.; Romo, D. Org. Lett. 2002, 4, 3231. (i) Haynes, R. K.; Lam, W. W.-L; Yeung, L.-L.; Williams, I. D.; Ridley, A. C.; Starling, S. M.; Vonwiller, S. C.; Hambley, T. W.; Lelandais, P. J. Org. Chem. 1997, 62, 4552. (j) Carnell, A. J.; Casy,
G.; Gorins, G.; Kompany-Saeid, A.; McCague, R.; Olivo, H. F.; Roberts, S. M.; Willetts, A. J. J. Chem. Soc., Perkin Trans. 1 1994, 3431. (k) Miyaoka, H.; Kajiwara, M. J. Chem. Soc., Chem. Commun. 1994, 483. (l) Solladié, G.; Lohse, O. J. Org. Chem. 1993, 58, 4555. (m) Taber, D. F.; Silverberg, L. J.; Robinson, E. D. J. Am. Chem. Soc. 1991, 113, 6639. (n) Nokami, J.; Ohkura, M.; Dan-Oh, Y.; Sakamoto, Y. Tetrahedron Lett. 1991, 32, 2409. (o) Corey, E. J.; Carpino, P. Tetrahedron Lett. 1990, 31, 7555. (p) Hatakeyama, S.; Sugawara, K.; Kawamura, M.; Takano, S. Synlett 1990, 1990, 691. (q) Gais, H.-J.; Lukas, K. L. Angew. Chem., Int. Ed. Engl. 1984, 23, 142. (r) Le Drian, C.; Greene, A. E. J. Am. Chem. Soc. 1982, 104, 5473. (s) Corey, E. J.; Wollenberg, R. H.; Williams, D. R. Tetrahedron Lett. 1977, 18, 2243.

(3) (a) Padwa, A.; Yeske, P. E. J. Am. Chem. Soc. 1988, 110, 1617. (b) Padwa, A.; Yeske, P. E. J. Org. Chem. 1991, 56, 6386. (c) Padwa, A.; Watterson, S. H.; Ni, Z. J. Org. Chem. 1994, 59, 3256. (d) Nunez, A., Jr.; Martin, M. R.; Fraile, A.; Garcia Ruano, J. L. Chem. - Eur. J. 2010, 16, 5443.

(4) Flasz, J. T.; Hale, K. J. Org. Lett. 2012, 14, 3024.

(5) (a) Anadu, N. O.; Davisson, V. J.; Cushman, M. J. Med. Chem. 2006, 49, 3897. (b) Seehafer, K.; Rominger, F.; Helmchen, G.; Langhans, M.; Robinson, D. G.; Ozata, B.; Brugger, B.; Strating, J. R. P. M.; van Kuppeveld, F. J. N.; Klein, C. D. J. Med. Chem. 2013, 56, 5872. (c) Forster, S.; Persch, E.; Tverskoy, O.; Rominger, F.; Helmchen, G.; Klein, C.; Gonen, B.; Brugger, B. Eur. J. Org. Chem. 2011, 2011, 878.

(6) (a) Carter, C. A.; Waud, W. R.; Plowman, J. Proc. Am. Assoc. Cancer Res. 1995, 36, 386. (b) Phillips, L. R.; Wolfe, T. L.; Malspeis, L.; Supko, J. G. J. Pharm. Biomed. Anal. 1998, 16, 1301.

(7) Tosca, P.; Merrill, J.; Ryan, M.; Knostman, K.; Johnson, J.; Peggins, J.; Tomaszewski, K. Cancer Res. 2009, 69, 5102.

(8) Peyroche, A.; Antonny, B.; Robineau, S.; Acker, J.; Cherfils, J.; Jackson, C. L. Mol. Cell 1999, 3, 275. (b) Chardin, P.; McCormick, F. Cell 1999, 97, 153.

(9) Colanzi, A.; Grimaldi, G.; Catara, G.; Valente, C.; Cericola, C.; Liberali, P.; Ronci, M.; Lalioti, V. S.; Bruno, A.; Beccari, A. R.; Urbani, A.; De Flora, A.; Nardini, M.; Bolognesi, M.; Luini, A.; Corda, D. Proc. Natl. Acad. Sci. U. S. A. 2013, 110, 9794.

(10) Blakemore, P. R.; Cole, W. J.; Kocienski, P. J.; Morley, A. Synlett 1998, 1998, 26.

(11) Bernet, B.; Vasella, A. Helv. Chim. Acta 1979, 62, 1990.

(12) (a) Mitsunobu, O. Synthesis 1981, 1981, 1. (b) Hughes, D. L. Org. React. 1992, 42, 335. (c) Martin, S. F.; Dodge, J. A. Tetrahedron Lett. 1991, 32, 3017.

(13) Davis, F. A.; Sheppard, A. C. Tetrahedron 1989, 45, 5703.

(14) Barton, D. H. R.; McCombie, S. W. J. Chem. Soc., Perkin Trans. 1 $1975,1574$.

(15) VanRheenen, V.; Kelly, R. C.; Cha, D. Y. Tetrahedron Lett. 1976, 17, 1973.

(16) Cha, J. K.; Christ, W. J.; Kishi, Y. Tetrahedron 1984, 40, 2247.

(17) Chaudhari, D. A.; Kattanguru, P.; Fernandes, R. A. RSC Adv. 2015, 5, 42131.

(18) Fukuyama, T.; Laird, A. A.; Hotchkiss, L. M. Tetrahedron Lett. 1985, 26, 6291.

(19) Inanaga, J.; Hirata, K.; Saeki, H.; Katsuki, T.; Yamaguchi, M. Bull. Chem. Soc. Jpn. 1979, 52, 1989.

(20) Glaser, R.; Shiftan, D.; Froimowitz, M. Magn. Reson. Chem. 2000, 38, 274. 